\title{
Economic-legal Securing of Integrated Territorial Development for Purposes of Housing Construction in the Moscow Region
}

\author{
Arkady Larionov ${ }^{1, *}$, Yulia Larionova ${ }^{2}$ \\ ${ }^{1}$ Moscow State University of Civil Engineering, Yaroslavskoye shosse 26, Moscow,129337, Russia \\ ${ }^{2}$ State Institute of Economics, Finance, Law, and Technology,Roschinskaya, 5, Gatchina, 188300, \\ Russia
}

\begin{abstract}
Condition and problems of housing legislation in ensuring of the complex development of the territories in Russia in general and in Moscow region, in particular. Conclusion of expediency of reduction and introduction of moratorium on legislative activity in the housing sector. Proved the necessity of the concentration of intellectual and financial resources of the legislator on the elaboration of organizational-economic mechanisms of realization of already created economic-legal environment of functioning and development of the housing market. Offered measures in the field of improvement of the legislation can stabilize the housing market significantly.
\end{abstract}

\section{Introduction}

Complex development of territories for the purposes of housing construction very depends on the level of development of the institutional environment. Adoption of new laws and normative-legal acts, which regulate the relations in the housing sector on the federal and regional levels, and amendments to the already adopted and applicable documents should be aimed at creation of the civilized housing market in our country. Formation of such market implies the achievement of strategic purpose, that is the improving of the living conditions for all citizens of all categories without exception, by satisfying the economic interests and expectations of all its subjects. Important factor of the development of the housing market on the modern level becomes its ecologization, in view of its demand.

Housing market in the Moscow region (Moscow and Moscow region) has a special place among the regional housing markets. Its largely owing to internal migration in our country. For decades Moscow region is a specific "pump", which pumps from the subjects of the Russian Federation the most energetic, powerful and advanced citizens. It caused by the fact that, on the one hand, regional power brokers didn't provide opportunities for selfrealization in the places for these people, on the other hand, its need for such people in the capital with its suburbs not only decreased over the years, but it grows. At the same time

\footnotetext{
*Corresponding author: proflarionov@mail.ru
} 
the level of the income is much higher here, than in the majority of the Russian regions. In this regard, economic environment should be considered a combination of time and space of activity of economic entities, carrier of the real objective and real subjective, perfect, material, management. At that social and economic are indissoluble: both person, and nature always work for a trend to balance [1]. That's why the basis of the complex development of the territories must be the formation of environment for life-sustaining activity on the principles of ecologization of the housing field.

\section{Methods}

Results of the researches of the native and foreign scientists [2, 3] allow to suggest that Russian government and regional authorities take certain measures for ensuring of complex development of the territories for the purposes of housing construction.

Positive results should include: in general, completion of formation of the economiclegal base of functioning and development of the housing sector (adopted by the housing code of the Russian Federation [4] and the amendments to the town planning code of the Russian Federation [5]; development of housing mortgaging, amount of mortgage securities market reached almost 400 bln rub.; mortgage products for social priority categories of citizens are implemented: of military, certificate holders on maternal family capital, young teachers and scholars, etc.; positive dynamics of the annual quantities of housing commissioning $(58,4 \mathrm{mlnsq}$ meters in 2010 to $79,8 \mathrm{mlnsq}$ meters in 2016 [6]; active drawing into economic circulation of housing construction of bank capital and personal savings of citizens through the development of mortgage lending (so, as of 01.01.2016 JSC "Housing Mortgage Finance Agency" refinanced more than 370 thousand mortgages worth more than 404 bil rub.; mortgages became the part of standard offer of banks and their portfolio increased up to 3,7 trillion rub.) [7, p. 9];

But the actual practice of enforcement of existing legislation in the Russian Federation in the field of housing $[1,2,3$, etc.] testifies about high volatility of economic-legal field of this segment of the national economy and the low efficiency of functioning both new institutions of its development, and created in the post-reform period [8]. All of that largely destabilize functioning of the housing market and doesn't allow it to develop civilized, market participants (primarily investors and owners of the real estate units) haven't possibility to satisfy their economic interests and expectations.

Norm on distribution on of non-residential premises, parking spaces in apartment houses of the rules of the residential areas, including on payment for the room, calculation of the area of the building in the Housing Code of the Russian Federation [9]; rules about determination of payment for living quarters, including the costs of communal community facilities are not clear (to be defined that in this case in part of the costs on communal community facilities, payment for living quarters can be represented as variable amount determined on the basis of amount of actual sum of costs on the communal community facilities with consideration of the existing regulations); there is no norms on the rights of the owner of the building, who received it due to the act from the developer to participate in the general meeting of owners with the right to vote, while they already obliged to pay for the premises; norm on the source of information about the square of premises, which is relevant in the case of appearance of the different information in registry authorities is absent.

Article 51 of the Town Planning Code of the Russian Federation [1, 7] provides that the decision to issue the permission for the unit commissioning its necessary to provide a technical plan of capital construction unit. In the permission for commissioning for the unit there must be reflected information about the capital construction project in the extent, which is necessary for implementation of its state cadastral registration and on the basis of 
this permission, statement of the unit on state cadastral registration is performed. Article 61 of the Federal Law from 13.07.2015 No. 218-FEDERAL LAW "On official registration of the real estate" provides the opportunity to correct errors contained in the Unified State Register of Real Estate. However, procedure for correction of errors, which contains the permission on commissioning, including information, which is necessary to enter into the Unified State Register of Real Estate is absent in the Town Planning Code of the Russian Federation [1, 7]. Stated above is the essential factor of containment of the complex development of the territories for the purposes of the housing construction in the Moscow region.

Law on joint construction [9], which comes into force 01.01.2017, provides: increasing of transparency of developers, which work on the money from "interest-holders" and response for developers for targeted use of resources; increasing of control from the executive authorities; creation of the unified register of the housing developers; provides the creation of special fund, which will be financed at the expense of the participants of "shareholding" for building of the apartment buildings (sum of amount is $1 \%$ from the estimated cost of the unit).

Strategic vector of the federal law on concession agreements [9] is targeted on the correction of behavior of the participants of the housing market for overcoming administrative-legal barriers, which prevent realization of the concession model in the field of housing and communal services.

Amendments to the Housing Code of the Russian Federation [2, 8] and the Federal Law "On water supply and sanitation" [8] are targeted on the empowering the Russian Government to provide the additional requirements for the native commercial banks, in which regional operator assumes to open and maintain current and other accounts, enabling owners to independently form and place on the deposit money, which are not used for financing of these or those activities on capital repair of the apartment house for some period of time, etc.

17.05.2016 on the meeting of the State Council of the Russian Federation on construction problems, Russian President V. V. Putin paid attention to necessity of completion of process of creation of the "rules of the game", which are distinct and clear to subjects of the housing market. In his speech, he expressed confidence that the historic chance to solve the housing problem in Russia is dropped namely today. In pursuing these aims he signed a number of key federal laws on amendments to the existing documents in July 2016 [1, 2, 7, etc.]. Thus, the adopted to the Town Planning Code of the Russian Federation $[1,7]$ amendments are targeted on the reduction of the financial burden to small and medium business in construction (only General Contractor is obliged to enter the selfregulated organization (SRO), subcontractors are free from such membership; only if the contract price doesn't exceed 3,0mln rub., company is not obliged to enter the SRO; contributions to the SRO funds are differentiated, etc.).

Research of economic-legal ensuring of the complex development of territories for the purpose of housing construction in the Moscow region showed unworked issues of termination of the land relations by the legislator. In particular, legislator doesn't define the what land is formed for the apartment building (with some necessary and permissible margins of the basement, equipped with children's playgrounds, recreation areas, access roads, etc.).

Quite often several apartment buildings that are being commissioned at different times are built on the plot of land: in the first apartment building of the housing complex first right of property is already registered (that means that land became the property of the residents), but on the same plot of land, construction of other residential buildings is continuing. 


\section{Results}

The results of our studies $[4,6]$ testify that appearance of this situation is largely conditioned by the absence of thorough investigation and contradictions in the housing legislation.

In particular, the Russian scientific, expert and professional community (developers, investors, builders) raises a lot of questions of context and the content of the priority national project "Affordable and Comfortable Housing for the Russian citizens". Abovementioned project [9] has been implemented in our country for more than 10 years, but many market participants, including the author of this publication, still wonder how affordable housing can become comfortable and comfortable can become the available one? Because qualitative products have high price always and everywhere and the housing is no exception to this rule.

Unfortunately, the key indicators of this housing megaproject have little common with the achievement of strategic indicators of the "accessibility" and "comfort". Moreover, the contradiction inherent in the interpretation of the name of the project, resulted the confusion of its purposes and tasks what resulted as discrediting of the very idea of the project and, as a consequence, to the absence of the expected results.

\section{Discussion}

Exploring the place and role of the legislation of the Russian Federation in the development of the complex land invasion for the purposes of the housing construction, it's impossible to ignore another important problem. It centers around that numerous amendments to existing legislation have negative impact on the functioning and development of the housing market. Moreover, it happens regardless of their (amendments) values, market actors sometimes don't just have a time to response them and make changes to their activities. Ultimately, attempts to improve the legislation in some cases cause destabilization of the housing market.

Understanding of not only the above-mentioned novels, but also previously discussed in our other publications $[4,5,9]$ changes in federal legislation, which regulates relations in the housing sector, indicates the adequacy of laws and other normative-legal acts. That's why it's understandable, what all the market participants can and should do. Another thing is how to do it? For this purpose, it is necessary to develop and implement organizational and economic mechanisms, which allow to achieve purposes in the documents mentioned above.

\section{Conclusion}

Stated above arguments and the results of the proper researches of the author of this publication allow to make two main conclusions:

1. Its viable to reduce the legislative activity in the housing sector (to put a moratorium on the legislative initiatives) and to move from the development and promotion of new laws and regulations to the performance of mechanisms of their realization and implementation of the already adopted and in force in the medium term (until 2020).

2. Scientific and Technical Council (working group) of eminent scientists and experts should be created at the Ministry of Housing and Building of Russia; representatives of the construction business, outstanding managers and specialists of housing field, the bureaucrats, who directly involved in the elaboration and realization of the housing policy, Russian and foreign manufacturers and suppliers of building materials, structures, 
engineering equipment, construction machinery, top managers of the largest commercial banks, etc. Strategic objective of this body should be the development of recommendations for the development of new and improvement of the effectiveness of the action of organizational-economic mechanisms of realization of the already adopted, and applicable federal, and regional laws, and legal acts.

\section{References}

1. V.Glinskiy, L.Serga, M.Khvan. Procedia CIRP,40, 625-630, (2016)

2. S. Garcia-Ayllon, J. L.Miralles. Procedia Engineering,118, 3-11, (2015)

3. S.G. Sheina, A.A. Khamavova. Procedia Engineering, 150, 1960-1965, (2016)

4. Y.V. Larionova, A.N. Larionov, S.A. Pavlova, N.G. Gorshkov, Rynokdostupnojzhilojnedvizhimosti: voprosy gosudarstvennogo regulirovaniya: monografiya,SGU, Moscow, (2013).

5. M. Bauer, P. Mosle, M. Schwarz.Green Building.Guidebook for Sustainable Architecture, Springer, (2009).

6. A.Larionov. Journal of Applied Sciences, 14, 2374-2379, (2014).

7. A.Larionov, E.Nezhnikova. ARPN Journal of Engineering and Applied Sciences, 11-3, 2023-2029, (2016).

8. J.Panibratov, A. Larionov. World Applied Sciences Journal, 23, 144-148, (2013).

9. R.Srinivasu, G. S.Reddy, S. R. Rikkula. International Journal of Reviews in Computing, 5, 15-20, (2011). 